\title{
"Practical Artillery."
}

\section{Captain T. B. Strange R.A.}

To cite this article: Captain T. B. Strange R.A. (1871) "Practical Artillery.", Royal United Services Institution. Journal, 15:63, 119-135, DOI: 10.1080/03071847109417039

To link to this article: http://dx.doi.org/10.1080/03071847109417039

$$
\text { 曲 Published online: } 11 \text { Sep } 2009 .
$$

Submit your article to this journal

LII Article views: 3

Q View related articles $₫$ 


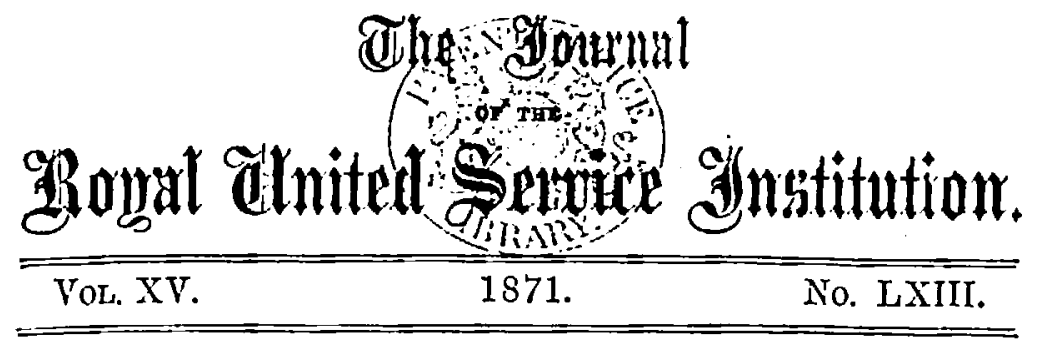

\title{
LECTURE.
}

Firiday, February 3rd, 1871.

General Earduey WILniot, R.A., F.R.S., in the Chair.

\author{
"PRAGTICAL ARTILLERY.". \\ By Captain T. B. Straxae, R.A.
}

L.uND servico artillery may bo broadly considered as-

1st. Field.

2nd. Siege.

3rd. Garrison.

The distinctive character of the first is mobility, of the last stability, or tenacity in holding its grond.

Siege artillery holds an intermediato placo between the two.

Artillery instruction may be divided into-

Scientific.

Technical.

Tactical.

I will commence with the last, not treating of drill, which is only a means to an end, or tho care of horses, a subject common to cavalry and artillery.

Field Artillery Tactics.

One of the noblest peculiarities of the Prussian Army is its power of Aclf-criticism, not nccessarily self-depreciation.

In the French " conferences militaires," just before the present war, we find littlo but self-satisfaction. In the Prussian retrospect of 1866 we have sharp censure, especially upon the artillery and engincer services. The l'russian artillery, rightly believing in long runge and the inadvisability of closing with musketry fire, fell into the opposite errn', and got too far to tho rear to support their infantry; six of their fieces burst, their fuzes were bad, and their fire was less eflicient than that of the Austrian gunners, who sacrificed themselves to sare a broken infantry.

roL. $\mathrm{Xr}$.

K 
In watching the French field artillery at Chalons (whero Marshal Bazaine commanded in the summer of 1869 ), I wạs struck with incongruitics. Their tactical action was free and bold to a degree; the divisional guns advancing with and in advance of skimishers, the large artillery reserves actingr decisively with eavalry masses. IBt this action was only possiblo on the plains of Chotlons; they were practising in jence what destroyed them in war. Their mobility was not real, for they had no means of carrying their gunners, cxcept on the wargons and limbers; the former were thus brought under fire, and the explosion of ammunition wargons paralysing whole batteries, were the first results of the present war. For imperial reasons, the unfortunate Frank had sinned against his own military maxims. IIow loner since Marmont wrote, "I o premier mérite de l'artillerie, apris " la bravourie des canonicrs, et la justesso du tir, c'est la molilité."

The Prussian gunners are carried on guu-axle seats and limbers, aut they liave saddles on the off horses for emergency, thus bringing a minimum of men and horses under fire, but sufficient for the rorking of the gruns. I believe they copied this system from the Bengal artillery, who practised it for more than a quarter of a century hefore the amalgamation. Thero were Prussian Princes present in the Punjaub campaigns. Prussian artillery oflicers have. becn attached to the Abyssinian expedition, and courteously shewn every detail of our service and arseuals. It is deeply to be regretted that we hare not insisted upon reciprocity in the present war. There is not one Britisl Artillery Oflicer leaming invaluable lessons from the siego of Paris, but our instruction has to filter through the "Times" correspondent, who puzzles himself and his reader's with dissertations on the superior capacity of spherical to cylindro-conoidal projectiles.

The Prussian detrospective pamphlet before alluded to, produced a storm of indignant commentary from senior Onicers, followed by a calm effort to take the advice griven. The results of 1870 show glorious amends for the shortcoming attributed to the sister scientific serrices in 1866.

In the English Army thero is nooflicial text book, nor any authorized rules for artillery tactics. In the Fuglish language I linow of no practical work on the subject, except, perhaps, the translation hy Colonel Maxwell, R.A., of a treatise by the Prussian artilleryman Taubert, somerrlat out of date; and the Incid chapter in Colonel Owen's artillery lectures. Colonel Sondy, R.A., has also ably collected forcign opinions.

Is this a proof that the subject has not receired due attention in the British Army? Ou glorious annals since Marlborongh ma be searched in rain for that grand application of artillery conmon to the Inperial Sous-Lieutenant and his great gunners Senarmont and Drouet. The reasons for this and other insular peculiarities lie too far back in time, and too deep in our social and military system, to be discussced here The fault, if it exists, does not lie at the door of the Britian. artillery, whose rolls bear such names as Congreve, Shrapuel, Dickson, Finzer, Ross, Bull and Norman Ramsay, Pollock and Henry lantrence. 
I think it is worthy of consideration that the great Duke nerer lost a run! is it that he did not habitually use the arm auyrliere near its limit of application?. Words of mine are of no value on such a point; let me refer to the soldier historian Napier, and take Busaco as one instance.

IIy plan shews the allied Army drawn up on those memorable heights, the French on the opposite side of a deep rooded ralley, "A "chasm so profound that the naked eye could hardly distinguish the "morement of troops at the bottom, yet in parts so narrow that "12-pounders could range to salient points on the opposite side." Four ronds crossed at right angles to the English position, from right to left of which a road along the crest afforded an easy communication. PIan 1.

Fifty guns were placed along the salient spurs of the English line, firin : down wooded declivities, apparently too steep for effectiro artillery fire, if we may judge by the graphic description of the light division skirmishers driven breathless and begrimed with porrder upon the guns (C), "which had to be rapidly withdrawn," until Crawford's shrill command sent "1,500 Britisl bajonets sparkling over" the brow of the hill," with a horrid shout, overthrowing the French column.

These guns on the salient spur in front of the Convent were subsequently effective against the flank of an attack in three columns by Sey, which rested in a pine wood. Two other enormous French columns under Reynier, attacked by the rond passing St. Antonio do Cantara, and actually effected a lodgment on the crest of the English position betreen the 3rd and 5 th divisions (F): "The right of the "3rd division was forced back, and the 8th Portugese Regiment broken s: to pieces; the leading French battalions 'wheeled to the right, in"tending to sweep the summit of the Sierra,' but at that moment Lord " Wellington caused tico guns to open with grapo upon their flank, while " a heary musketry was still poured into their front, and, in a little "time, the 45th and 88th Regiments charged so furiously that even "fresh men could not hare withstood them. The French, quite spent is with their previons efforts, opened a straggling fire, and both parties, " mingling together, went down the mountain side with a mighty "clamour and confusion, the dead and dying strewing the way eren "to the bottom of the valley."

To an artillery eye the key-stone of an arch of strength (like the position of Busaco) undoubtedly mas, instead of dotting guns along the face of a declivity they could scarcely search, there should havo been an artillery reserve, with the heavy casalry on the plateau at $(H)$, or concealed behind the convent, to wait until the French attack dereloped itself, in mighty columns along onc, or other, or all of the three roads, leading to the right, centre, and left of the English position. Then the artillery reserve on the road along the crest which Napier says "afforded an easy communication from right to left," could hare acted with crushing effect on the head of an attack by any of the three roads at right angles to that on which they moved, and in the event of such a crisis as the Freuch penetration between tho 
3rd and 5th division at (F), consider the effect of a dozen guns instead of the inevitable two turned on by Lord Wellington.

Let us follow the other possible uses of this reservo of guns. " On " the evening of the 28th, when Wellington, though he had gained a "victory, found the French had turned his left, looking at the distant "columns with great earnestness, he scemed uneasy, his countenance "wore a fierce, angry expression, and suddenly mounting his horse "he rode away without speaking. One hour afterwards the whole "army was in motion; in retreat, abandoning stores of harness, tents, "shoes, spirits, salt meat, \&c., withdrawn so unskilfully that a troop " of French dragoons, which had passed the ford, now came close upon " the flank, and a single regiment of infantry would have destroyed " the division, wedged as it was in a hollow way, and unable to " retreat, to advance, or break out on either side." A reserve of mobile artillery acting with the cavalry, on ground favourable to both arms as it was about Milheada, would certainly have stopped the Frerich deployment at Boyalva, if it did not annihilate them.

"The march by which Busaco was turned, was a violation of tho "soundest principles of war. In a purely military view the English "General may be censured for not puuishing his adversary's rashness, "who violated all three of Napoleon's greatest maxims, threw " his whole army into a narrow defile within ten miles of an enemy in "position, with much disorder. Massena's army was not then in a " condition to fight, and he had abandoned his line of communication " without having established another. Wellington was within four hours "march of either end of the defile through which the French army "was moving; he might with the 1st division and the cavalry, the "Portugese regular troops and Trants militia, lave presented 12,000 " or 14,000 men at "Sardao,' to head the French in the defile."

Such a force, with the Jiobile field artillery of a reserve, should have done so, "while the 2 nd, $3 \mathrm{rd}$, 4th, 5th, and light divisions ad"vancing by Martagoa assailed their rear. That he did not do this is "to be attributed to his political position $* *^{*} *$ nevertheless " his retreat was as dangerous as such an attack would have been." It is difficult to understand any political position forbidding the annibilation of an enemy. The description and military opinions are Napier's - the artillery application alone is mine.

For obvious reasons I have drawn a lesson from the annals of a glorious war, in which most of the illustrious actors have passed away. I am unwilling to touch upon the field artillery incidents of the Crimean campaign, in which $I$ had not the honour of bearing a part. Kinglake gives us a crisis evolved also out of tiro guns, served by artillery Staff Oficers on the Alma knoll. The gunners had been teft behind for want of gun axle seats, and saddles on the off horses. Fifteen years hare: passed, and we are still without the means of carrying field artillery. gunuers, though it is believed that gun axle seats without foot-rests, and saddles without stirrups, have been sanctioned. The French are the only other field artillery who have not yet found a means of carrying their-gunners. Our splendid horso artillery are the only really mobile portion of our service, but the expense of this branch and 
the necessary lightness of their guns will always restrict their number.

Iy remarks hare mostly pointed to things we ought not to hare done, or have left undone. ITith the object of proving that the past can be no model for the future, I venture now to give a few broad artillery maxims, upon which my brother officers have been for somo time tolerably unanimous, and which appear to be confirmed by tho practice of the present war. Anyone who expects to find artillery tactics reduced to a ferr cut and dried rules for invariable application, inust be disappointed, as the nature of the ground, and other concomitant circumstances must be an erer-varying element in such problems. A practical knowledge of tactics is not likely to be acquired by any branch of the service, until the Legislature passes an Act permitting the movement of troops across country for a few weeks after harvest. The existence of this law in Prussia has euabled her Army, after half a century of peace, to step into the arena of Europe as a conqueror.

The questions in Prussian military examinations are few, and ample time is given, the answer being a short essay, to test the thinking power of the pupil, rather than an exercise of memory, as with us. We cram with details, instead of teaching the habit of thought.

Ficld artillery taclics may be broadly considered under two heads1st, Dirisional, or simply supporting the infantry, paving the way for its advance or covering its retreat.

2nd, Reserve. Acting and striking en masse, in obedience to tho will of a master mind.

\section{Divisional Artillery.}

Great freedom of action must be given to the Battery Commander, who should erer have before lim the golden rule of Taubert, i.e., "Divisional artillery, like divisional cavalry, is merely an auxiliary "arm; and that the infantry, and not the artillery, is the chief " element in an action. It is therefore the duty of that artillery to "comprehend the object momentarily in view, with quickness and "accuracy, and porrerfully to support the infantry in combat." The "Prussian Infantry" pamphlet says that, without artillery, infantry cannot act against infantry on the defensive, and oven artillery, firing direct at infantry in shelter trenches, cannot shake them, as at Spicheren (Plan 2), where the Prussian artillery failed to move the French on the crest of the hill, until batteries took up positions in prolongation of their flank, and rendered possible the final successful adrance of the infantry. In this case, the inefficiency of direct artillery fire, as compared with flank fire, was enhanced by the fact that the Prussians uso only a percussion fuse and a common shell; firing at a position on the crest, all shells aimed high, flew harmless; those aimed low, stuck into the ground, and produced but little forward effect.

The division artillery is under the command of a LieutenantColonel. A pamphlet by Sir Augustus Fraser, at the close of the Peninsular WVar, says, "With respect to the Field Oficers of artillery "with an army, they are, by the present distribution of the arm, 
"placed in a rery singular situation. They are appointed to, and " understood to have the command of two batteries of field artillery. "But these batteries, being attached to a division of the Army, are " habitually separated from ench ather:. In conscquence, the Field "Olficer cannot be with both; his presence with either is displeasing "to the Oficer comminang the battery, who naturally wishes to "receivo the credit of acting independently; and the Field Oflicer is " reduced to the alternative of either doing nothing, or of interfering "with the commard of a Captain, probably very competent to the " charge of his own battery."

The Lieutenant-Colonel of artillery should be inseparable from his Dirisional General, with whom be ought to be en rapport, and transnit his orders to tho Battery Commanders by his two galloppers, the $A d j u$ taut and Acting Quartermaster, keeping a trumpeter with him. The new Army Signal Code ouglit to be habitually practised for directing the conccntration of artillery fire, especially by meaus of Lancer cscorts, whose gay pennons, in instructed hands, form the readiest method of conveying orders and information.

The stereotyped idea that artillery must conform to its infantry, dressing by them, \&c., must be for ever dismissed, except for parade purposes. It : was perhaps admissible when the Enfield rife and smooth bore field gun were associated.

Now the limit of infantry fire is the commencement of artillery efficiency, whose guins should not be pushed closer, except when the gain to the infantry will be commensurate with the certain loss to the artillery.

At Gravelotte a field battery was pushed up to the French sheltertrenches ( 600 yards); four guns were destroyed while advancing; the remaining two produced no effect, and were nearly lost. $\Delta$ battery of horse artillery, taking advantage of gravel-pits to conceal their adrance, and cover their horses while in action, maintained its position with great gallantry at 700 yards, but produced no effect, and two of the guos had to be thrown into the gravel-pits to prevent capture.

The strict alignment of guns with infantry compels them to fire straight to the front, which is not usually the direction of the enemy's greatest depth, fanking or oblique fire being most effective. When so aligned, throwing the trails of the guns outwards gives this effect; for when the dlank is thrown forward it is exposed, and the pieces should be cchelloned, the intervals being also increased:

Instend, however, of tying artillery to its infantry, the former should bo given an escort of the veritable dragoons, i.e., mounted soldiers with rifles, "who fight indifferently on foot or horseback," according to Dr. Johnson. Ile had as little idea of using. the word' indifferently in its modern sense as I have.

It is most important that a feeling of strong " cameraderie". should exist between the battery and its escort, which always springs up when they are habitually furnished from the same regiments.

In default of mounted infantry, the Prussians prefer Jäger escorts, and our own rifle brigade are incomparable on this serrice to any troops in the world. 
In advancing into action the 1st Captain rides several hundred yards in front, to sclect a position. The battery is bronght up by the 2nd Captain, in obedience to the sword am signals of its Commander, who may also take his trumpeter." A dozen. mounted dragroon "eclaireur's" to accompany the Captatin would render this service more effectire, and perhaps save tho battery from the loss of its leader. Sixty gunuers, armed, momnted, and trained as escort "eclaircurs," would render the battery sclf-smporting, and free to strike for its infantry from the most advantageous position.

Such a reserve of mounted dragoon gunners would also be available to fill up casualtics, or get a gun any where with lasso-harness.

'The points for consideration of a position are in order of importauce :-

(a) Finiciency of fire.

(b) Cover for the pieces and limbers, if possible:

(c) Pusition of the other troops.

(d) Fucility of retirement.

(c) Facility of advance.

"Thesc conditions are seldom united in an equal degree. The Cap" tain must at once decido which is the most important to secure the " object of the engragement, and which to give up, as least essential." No position can be called a good one that does not fulfil the first condition.

Guns shonld not lie placed inmediately in front of other troops; a donble target is thus offered. Prussian cavalry rudes through two batteries at Rezonville; the French infantry in rear fired at friend and foc. This lappened to two batteries in succession with infantry in rear. Gumers atmed rith revolvers could take shelter under the guncarriages, till the civalry storm swept past, the limbers retining in front of it; while the loiterers behind a charge are not the sort of inen to prod a revolver-armed resoluto grumer out of his retreat.

When the moralc of the enemy is not good, batteries may efiectively be pushed forward with skimishers and a few light troops, producing great results with but little expenditure of the other ams. This was our practice at the close of tho Indian Mutiny, and tho Prussians acting against French moblots and Garibaldians near Dijon followed the same tactics.

Mbout Le Mans the country is much enclosed, like Engrland; the I'russian artillery never attempted to mancenre, but the oflicer carefully rode out and selected a position, and generally remained in it, often silent, rather thau waste ammunition by firing without a clear view. Om Onicers require a ficld glass, like the Staff, instead of the' generally empty pouch belt. Except for defensivo positions, our close country is nost unfarourable to the developnent of free artillery action. The artillery eyo-witnesses of the present war are all inpressed with the idea that tho absence of a range-finder is the great artillery defect on botl sides. 'Trial shots are uncertain, and uumask your batteries; the large bursting charge of the l'ussian common shell is an assistance in indicating tho range.

The French, it is said, in addition to divisional reserve artillery, ate 
cndeavouring to re-introduce battalion gune, which prores their utter want of self-reliant infantry. The pieces are light and long ranging, on the Whitworth principle, a small hexagonal bore and rery elongated shell.

- Guns should not be placed immediately in rear, as again giving a doublo target, except in such positions as Scdan, whero an amphitheatre of hills allowed their conserging fire to act over tho heads of the columns, and gavo increased certainty to the action of their percussion fuzes. Plan 3.

The reverse of a gentle slope, Fig. 2, not cxcecding $4^{\circ}$, with gun muzzles only appearing over the ridge, is generally farourable, but trienty minutes work with the entrenching tools on the limber will give excellent gun pits, in which the principal advantage of the breechloader gun is apparent.

When the opposing guus aro on higher ground, Fig. 3, the reverse of a slope is sometimes most disastrous, the ground acting as a natural glacis, coinciding with the descending trajectory of the cnemy's fire, as at Inkerman. An advance over the ridge is the remedy for this evil, which will at once make itself felt.

It is needless to remark that during all infantry deployments their fire is lost, and changes of front should be covered by the divisional artillery skeeping the face of the new aligument. Fig. 4.

I am of opinion that the Russian and Austrian unit of cight guns per battery is best suited for tactics. In peace it can be reduced to six or four, and is easily expanded, no more officers being required, tho lst Captain being a Major, and the 2nd Captain taking charge of a division or half battery when necessary. A flying column can seldom take more than a battery, and will wat to work with a half battery on eitler flank. Four guns aro almost as effectivo as six, while three on ench flank break up one subaltern command, and if it is required to reinforce a flank thero is a difficulty, for it is not allowable to leare one gun on a flank, or seud it away alone. Each division of trro guns is complcte in stores for repairs, artificers, \&c., and can bo detached on any servico under its Subalteru Commander.

\section{Tactical use of Artillery under the second head, viz., Rcserves " $a$ la Grand" Tactique."}

"The general engagement onco begun, he who has the address to " bring suddenly and unknown to the enemy an unexpected amount of "artillery to bear upon tho most important points, is sure to carry "them."

This was the dictum of the Artillery-General Napolcon tho Great.

At the oft-quoted battlo of Friedland, " 36 pieces were collected "from different divisions by Senarmont, who commanded the French " artillery; this concentration of the divisional artillery was contrary " to the wishes of the Generals, but was done with Victor's consent, " silencing the Russian batteries on the right bank, and driving tho "infantry into the defilo before Friedland. Tho Russian cavalry "attempted to check the alrance of the battery, but Senarmont 
" promptly changed front, and repulsed it with ease. Napoleon him" self was astonished at the effect produced by this battery acting " thus independently. The defeat of the Russians was complete, and "their loss severe." The final concentration was duc to the confined space, and the short range of smooth-bore guns; to copy this action Fould be an error with rifled artillery.

Taking the artillery from a division to form a reservo is, howerer, inadrisable; it destroys the divisional tactical unit, and tends to disspirit any but the most self-reliant infantry.

The artillery reserve is as essential to an army corps as the cavalry division, and is as much a tactical unit to be placed under a selected Artillery-General.

It is probable that the increase of artillery range will lead to a different mathod of reserve application, viz., concentration of fire, but dispersion of batteries.

With smooth-bore guns it was necessary to agglomerate batteries, so as to produce an effect on an objective point. The same result may be produced by concentrating fire from batteries sent to different points for the purpose, or by directing the concentration of the divisional artillery fire by army code signals.

Both French and. Prussians find it necessary wincrease the intervals between the guns of a battery from 20 to 40 yards, when exposed to the enemy's shell fire, the bursts of which are found to be so laterally destructive. When it is wished to increase the artillery power at a certain point, a fresh battery is sent up to take part between the interrals, and damaged batteries are relieved by fresh ones from the reserve in a sinilar manner.

These methods hold out many advantages orer concentration of guns in an unwieldy mass, which cannot well be forced into action without dislocating the line of battle. Eighty British guns or thereabouts were once drawn up in rear of, and it was said in support of, allies, without firing a shot; two batteries only were employed on the flanks of the general engagement. In the event of disaster, guns so placed can give no support; friend and foe are mingled in a mass, against which no man could fire, unless indeed the position was sufficiently high, and the combatants far enough apart, to allow of discriminate artillery action. This would hardly bo the case in retreat; and an unwieldy mass of guns and ammunition waggons driving helplessly to the rear would block up all roads, amid a storm of anathemas from friends, if not projectiles from foes.

At Gravelotte, however, cighty-four guns, with hussar supports, galloped up a ravine which concealed their approach. Plan 4. The three first batteries, under an Artillery General, on deploying, found six mitrailleurs in action; the whole eighty-four guns were concentrated on the nearest mitrailleur; there remained nothing of it but wreck. The same with three others in succession; the two last did not wait for this annihilation. The eighty-four guns were crowded, to aroid drawing firo on a field hospital in rear of the intended alignment. Nevertheless, by concentration of fire, the French guns, about equal in number, were silenced in succession, tho aifference between French and German artillery fire 
being that the former belicre in "fen d'enfer." . When thoy think the enemy is in front, they blaze away quickly. The Prussians generally avoid the fire-swept-zone; when French men and ammunition are exhausted, they attack. Excessive deliberation and careful pointing are the peculiarity of Prussian artillery fire, and nothing will induce an officer to waste ammunition unless he sces his object.

More than ever, artillery action requires an artillcry head, but no English Artillery General has ever been permitted to command a British army, or eren a division, in Europe.

It is sad to read what a distinguished veteran before referred to, wrote, in 1818, at the close of his campaigns. More than half a century has passed array, and yet is there any improvement in the status of the Artillery General, whose most important functions on scrvice will be usurped by the omniverous Control Department ?* Any service, the represcntative chicfs of which, are systematically orcrlooked; must deteriorate.

Sir Augustus Fraser says: "Let us consider what is the present " situation of the Officer commanding the artillery of any Army. Ho " is expected to be responsible for all that is understood by the effi"ciency. of the arm when it joins the Army, it is subdivided and placed "in rarious "ans under the command and superintendence of the "general Officers of the cavilry and infantry; so that, with the " exception of attending to its wants in men, horses, ordnance, and "stores, and of endecizouring by correspondence with the Department "in England to obtain the necessary supplies, the Commanding Officer "of artillery may be almost said to lave little to do with the arm "in the field. IIIs opinion, we hare scen, is not asked as to the selec" tion of the arm for service, and it is as clearly never required "for the distribution of it afterrards. Ile can seldom be known to " his Commander but by the wants of the arm, or by the sius of the "system. Can it be wondered then that, rarely coming in contact but " on these ungracious occasions, he seldoms obtains the consideration "which he does not appear to deservo? As to signalizing himself by " any application of the arm in the field, it is ont of the question. . He " remains an individual without the power of moring a single gun."

\section{Iforse Artillery.}

Nerer having had the honour of serving in this distinguished branch, I have not touched upon its especial tactics. Future wars will, I believe, give it a wider field of employment, both as a reserve to strike quickly and decisively ; and also to give to our Uhlans the power of holding what they touch, a proportion of horse artillery Gatlingguns with cavalry would, I believe, be a happy warriage of fire and steel in the feelers of an Army. At the most favourable ravge against targets, 4 crrt: of ammunition from Gatlings produces three times the result of 12 crt. from field guns; or nine times the effect; but field guns could destroy the Gatlings at long range.

* Which Sir Trilliam Mransfield calls a system for uneducating Generals. 


\section{Siege and Garrison Artillery.}

Siege and garrison artillery tactics iuclude the attack and defence of fortresses, as well as tho tactical use of the latter, with an Army acting under their protection, or pivoting upon them, and runs into strategical considerations of bases, depôts, and lines of communication; too large a subject for this paper. It will suffice to say that tho fecble defence of the mass of French fortresses is attributable to their ancient construction and armament; a system of fortification 200 ycars old, is miscalled modern, and a mass of honses crowded into a weak enceinte have crumbled rapidly into ruin, under tho concentrated fre of. Prussian guns, defended, as these fortresses appear to have been, by orerybody bui garison artillerymen. The comparatively protracted defence of Paris by detached forts appears to point to tho advantages of a salient system of Moncrieff-pits, as also the disadvantages of embrasures acting as shot-funnels to an enemy's projectiles.

The Prussians hare largely emplojed tho barbette system. It would be seen if they approached closer for breeching purposes, whether the French fire would be sufficiently accurate to dismount guns so placed. Against skilful and unopposed fire, as at Shoeburyness, such guns would be put hors de combat in: a few minutes. Iucreased range of modern artillery gives a wide field for the selection of sites for enfilade batteries. A considernble distance bejond the salients of Mont Avron were woods; behind these, Prussiau batteries were made, and armed unseen. The trees in the line of fire wero partially sawn through, and fell with the first discharge, leaving unimpeded the path of their terrible projectiles. Thionville was reduced in tho same manner; only one battery was in the open, and that a screen battery, such as we make at Shoeburyuess. Only onc round each quarter of an hour was allowed from any gun. This was to ensure accurate laying, and possibly also for fear of damage to brench-loading apparatus:

It may be interesting to lnow that this application of a natural screen liaring been foreseen before the present war by us of the Royal Artillery, an experiment of the same sort was carried out at a sham fight, the locality of which shall be nameless, or the experimentalist would certainly hare a heary bill of damages laid to his charge, though the real value of tho destroyed Government timber was only a few shillings, the amount demanded : would doubtless cool his military ardour.

The resistance of the Paris revetments and casemates rewains to be compared to tho sjstem in some Prussiau forts, which have no escarps but slopes of earth, and rely upon flauk fire and counterscarps agaiust a coup de main. The effect of concussion in continuous fire of rery heary guns in casemates, may have the effect upon artillerymeu which a naral Officer informs me continuous heary fire has upon British tars, of all men tho least nerious; it is said to be a slock from which men and Officers suffer for days. It is reported that the crews of guns in Paris cascmates had to be reliered frequently, and often fainted at the gun.

The Prussians are getting to feel the disadrantage of using only one 
projectile, common shell and percussion fuze; firing up hill or into soft ground they fail (Fig. 5). They are introducing Shrapnel and a timo fuze. Trusting to one nature of fire appears rather like a quack doctor who has but one pill for all cases. I cannot but believe they have copied much that may be seen at Shoeburyness, but are still some way behind us in technical artillery matters. In artillery tactics they are in advance, possibly because artillery tactics have never been in the hands of artillery Oficers,

As regards our field and garrison artillery, malériel guns, and ammunition, \&c., I believe it has always been the best in the world, and as long as England maintains her manufacturing supremacy, will, I trust, remain so, in spite of adverso criticism from home and foreign sources.

\section{Technical Artillery Instruction-Field, Siege, and Garrison.}

Improvements in artillery matériel are thought by many to be worse than useless, unless accompanied by a corresponding increase of intelligence and training. I believed I was giving voico to the wish of a large proportion of my brother Officers, when I proposed a plan for encouraging this professional knowledgo among the rank and file, or applying it, where it exists, by selecting the best qualified Nonconmissioned Officers or men, for pointing our guns in action. Our expensive modern projectiles will be worse than masted in war, as they are in peace, fired away by men who may be short-sighted, unable to adjust a tangent scale, or incapable of setting a fuze to a given range.

Some years passed in daily instruction of the rank and file of the Royal Artillery, have impressed me very painfully with the vast importance of this subject, about which I cannot think myself mistaken.

There is an absolute necessity for adopting some system of selection in our artillery, unless we are content to be swept from future fields of battle with bloodshed and dishonour, as an imposture, an incumbrance to a self-reliant British infantry, armed with terrible breechloaders, who will only ask us to batter buildings or expect us to fire at nothing smaller than a town. Unpalatable as such expressions may be, there is nothing gained by dishonestly shirking conclusions that may be drawn from the results of the late and present campaigns, and from the deliberate trials of the Dartmoor Committee. Their report shews marvellously few hits when the circumstances approached nearest to the probabilities of actual war, viz., unknown range, uneven ground, and rapid fire; add to these the element of nervousness and confusion, and you would have still less than the results reported upon by the Committee "as so unsatisfactory, and the expenditure of ammunition so inuch out of all proportion to the effect produced." The success of Captain Nolan's range-finder, together with a system of picked marksmen trained to its use, would I believe, when combined with mobility given by gun-axle scats, again restore to field artillery its destructivo superiority over the other arnus.

The French artillery choose the best shots with carbines as likely to 
bo the best natural gunners, and a further selection is then made by the inexpensive plan of trials, by pointing guns at objects against time, but without ammunition, and lastly by actual firing at a target. These selected men are termed "pointeurs," and every gun in peace or war is laid by one of them; there being sufficient in each battery to make up casualties. It will be time enough to object to copy the French field artillery in anything; when it can be proved that they have failed in everything. When the mists of passion shall have blown off the present contest between France and Prussia, it will, I belicre, be found that the regular French artillery havo not utterly failed, but lost heavily in boldly supporting and saving their infantry. Their free tactics (combined with certain defects in matériel, I shall not dwell upou here) have caused loss in guns and men It is doubly painful that some would prefer retrograding to a less efficient weapon, rather than educate our gunners up to our arms of precision. Because our national qualitics make us good gunners, our men aro phlegmatic to a fault. The Teuton and Scandiuavian blood gives that cool precision in action which the excitable Gaul has failed to shew. The French artillery Officers knew their national defect, and tried to remedy it by selecting gunners as much as possible from Alsace. Gunnery education is only possible to us by a system of selection and prizes, not necessary to the Prussians, because all their men are edducated. The French rank and file are more like our own, mixed and very varied in education.

Restricting the annual practice to a certain percentage of the most intelligent and keen-sighted Non-commissioned Officers and gunners of each battery, would reduce the expense below that of the present wasteful system.

As regards the garrison brigades, a little modification in the amount allowed for annual practice would, without extra expense, meet the requirements of competition, a considerable portion of which might be carried on with the old smooth-bore ammunition, all but obsolete, encumbering as it does our Controllers, with the charge of pyramids rivalling that of Cheops. A preliminary instruction and examination by subaltern Officers before sending in the names of those selected for practice in their divisions would benefit both Officer and man, refreshing the half forgotten knowledge of the former, increasing his interest in his profession and his men, giving him a measure of their intellectual calibre, and enabling him to recommend. for promotion with justice and confidence; while there would be a reaction of kindly feeling and respect from the men to their Battery Officers, who in garrison brigades, as matters now stand, hare little to do with them except in the routine of orderly duty. The majority of Subalterns in the Royal $A$ rtillery have reached an age when men in other branches generally command companies, and sometimes regiments. They might be entrusted with the instruction and selection of their marksmen.

Gunners' nature is only humain nature: the Royal Artillery have no rewards for efficiency, while infantry, caralry, seamen, and marines and Volunteer. $\Lambda$ rtillery, receive extra pay or prizes for proficiency with their special weapon, be it sword, lance, rifle, carbine, or great gun. 
Lord Straithnairn, when Commander-in-Chief in India, introduced a system of competitive practice for the artillery, with extra pay and prize-badges as for infantry: it is very variously spoken of by artillery Officers. All are agreed that being carried on entirely with smoothbore guns, the results were much modified by chance; the admission of drirers and shoeing-smiths (who would rarely, if ever, have to lay a gun on service), \&c., into competition with gunners and Nos. 1 was thought a mistake: every man to his calling.

Prize-pay and a badgo of cross-whips might be given to a certain percentage of the best drivers, whose horses were in good condition. 'Those Olficers who adhered to the spirit of Lord Straithnairn's instructions allowed no man to compete, unless ho uiderstood the elementary principles of gunnery, the setting of fuzes, was perfect at drill, and a first-class judge of distance. In fact, they who tried the system fairly, speak in the higliest terms of the spirit, of emulation and efficiency it produced, especially the preliminary instruction in barrack rooms by the Subaltern Oficers.

Iraving been asked by many of my brother Officers and some members of the Committee, to draw up for the Institution-Papers the outline of a scheme for competitive practice, I ventured to do so with the hope that general attention would be drawn to the subject, and errors I have made, be remedied by the suggestions of any of my brother. Officers.

I have made the amomnt of ammunition approximate ns much as possible to that already allowed, and have assimilated the system of scoring to that laid down by the National Artillery Association, at Shoeburyness, which works without trouble in the Volunteer Artillery competitive practice.

I wish to draw attention to what I take to be a blot in our system of artillery, riz., that though the instructors very justly receive extran pay for extra work, the pupils have no reward or inducement. In the ranks are mingled those who cannot read the figures on a fuze or tangent scale; and others of excellent education, grent natural powers, and quickuess of sight. It must be most reprehensible to liave no system of selection for marksmen and range-finders, and to apply the same dull routine of training to all.

We all know that Non-commissioned Officers aro selected for many excellent qualities with which gunnery proficiency has nothing to do. 'There is an vitter disbelief in all gunnery, and necessity for straight shooting among a few artillery Officers, whose professional education ceased before the introduction of modern weapons. The sooner this opinion is honestly expressed and argued out in black and white, the better for the English people: for the question, though it takes its rise from a small portion of the service, has national issues. I am glad to say that a Committeo has been appointed to decide upon the details of a system of selection and prizes.

The garrison artilleryman is undoubtedly the soldier of most varied accomplishments; from him is required the steadiness of a guardsman, the lieenness of the rifleman, combined with the rough and ready energy of a sailor in handling heavy weights, ropes, tackles, and 
mechanical appliances, together with a knowledge of the varied armaments and stores of the artillery service. Laying, loaiding, ndjusting the fuze, pointing and firing his $\mathrm{gm}$, are tho least arluous and important of his duties. The monster modern guns of 12, 18, 25, and eren 35 tons lave first to bo mounted inside and on the top of casemates, by means of gyns, shears (sce models), hydraulic lifts, inclined planes, \&c. In war, disabled guns and carringes would hare to bo remored and replaced, without the aid of gyns or sleers, too conspicuous for use within range of rifled guns. - $\Lambda$ whole front may hare to be disarmed with all possiblo despatch, and the guns, carriages, and platforms transferred to another face, exposed to the real pressure of attack apprehended from another quarter.

Our Artillery Officers, sent in more liberal times to acquire information on the Continent, tell us that they saw this operation performed in an incredibly short time, at the annual inspection of an Artillery General in Russia, where the fortresses are invariably under the command of an Artillery' or Engincer Officer. Repairing damnged embrasures and platforms, raising and thickening parapets, putting an extra layer of earth on bomb proofs and magazines, essentially artillery duties supposed to be performed by engineers, would in the exigencies of war hare to be carried out by artillery, assisted with infantry. It is to bo regretted that classes of artillery are not sent down to Chatham, to profit by the siege operations carried on there. The instruction at the School of Gumnery, Shoeburyness, is most excellent, but there is no fortress to besiege, and it seems a pity to carry on instructional siege operations mithout gunners.

Military brilging and rafting for the transport of heary ordnance, as well as embarking guns, form part of the admirably practical Shoeburyness course; for it is most important in war that artillery should be self-reliant, and not obstruct the bridges made foi the rest of the Army by the engineer train, who are not, however, always at hand in minor operations, where the artillery must fall back upou their own resoures.

In all wine-growing and beer-drinking countries, cnsks are always procurable, and, together with the salt pork, flom; and empty rum casks of the commissariat, are at hand. 'These, with a lashed superstructure of rafters and floors from adjacent housns, form rafts capablo of transporting the heariest artillery with its ammunition, carriages, harness, \&c. Horses are swum across, or can ford where the water would cover the ammunition boxes.

The Prussian retrospect comments on the inactivity of the artillery of an army corps on the wrong side of the river Bristritz, in the absence of the pontoon train. It is unfortunate that this sort of service is scarcely recognised by us or calculated upon, and has only been occnsionally performed on emergency by some unusually self-reliaut officer.

Our sil rer streak renders the disembarkation of artillery a perpetually recurring event. Ably as we have been assisted by our brother blue jackets of the Navy, our artillery in future wars will be more than erer self-helpful, thanks to Shoeburyness. 
Being fond of false economy, we have never commenced a siege with an adequate siege train, but as the sea must bo our base of operations, we hare always fallen back upon tho Navy for guns; these and their carriages not being suitable for going across country, have to be taken to the front by various expedients, which require that the Royal Artilleryman and his friend Jack should be, and have proved themselves, the most indefatigable and shifty of mortals. But Jack and his guns cannot be in two places at once. Is it not probable that the withdrawal of sailors and guns from the French flect is the reason why, like our own in the Crimea, though rendering glorious service on shore, it can scarcely be said to have achiered much on its omn element?

When it is considered that artillery improrements must be rapidly progressive, and that it wonld be impolitic, if not impossible to recall from distant stations and reject for service, guns and stores of a comparatively old, but scarcely loss efficient pattern, it is the firm conviction of Artillery Officers best acquainted with the service, that the Royal Artillery can never be efficient until the care of their own special weapons and stores is taken from tho control, separated from "munition de bouche," and handed over to the artillery. You select artillery officers by open competition, they are scientifically and practically instructed in the manufacture of guns, powder, and all the complicated material of their service, and yet you take from them the most important part of their duties, to be handed over to civilians! In addition to the ordinary courses of artillery instruction, there was an annual class for Officers coming from out stations, as inspectors of war stores, but the new control officers were naturally found so ignorant of a service for which they were not educated, that the laboratory department could not stand the strain of instructing them; and the Artillery Officers who wished to acquire a knowledge of the latest inprovements in their own arm, were put off every alternate year to make room for the instruction of Commissariat Officers and others in duties that are essentially artillery. This is not likely to be borno without deterioration of esprit and efficiency by any body of Officers. As for the Non-commissioned Officers and rank and file, with whom the eye educates the mind, efficiency cannot be expected, as long as they are relegated to infantry drill, varied by the occasional handling of the obsolete smooth-bores which still encumber our forts. The artillery duties of transporting and embarking the newest guns and ammunition in our arsenals are given to the Army Service Corps, who it is said are to be increased to meet these requirements. This duty was formerly entrusted to the garrison artillery, who, with the artillery drivers, also employed in Woolwich arsenal, formed an artillery reserve, arailable in war, which we drew upon for tho Crimen, their places being supplied by civilians with contract teams.

\section{Reserve Artillery, Militia, and Volunteers.}

The necessity for instructing 50,000 Militia and Volunteer Artillery, eager to learn, but who have no professional artillery chief, opens a 
wide field for the energy of the regular artillery. Such a vast organization to be brought into being will, I hope, lead to the appointment of some Artillery Oficer of rank and known professional ability, to the position of Director-General of Artillery Instruction, which at present, with its numerous departments, the Royal Military Academy, School of Gunnery, Advanced class, Laboratory, Gun Factory and Carriage Departmental instructors, requires a head.

I have not space to touch upon the scientific instruction of Artillery Officers. It is sufficiently well known and ackmowledged in this country, where we can register the relocity of a shot before it leares the gin. A report upon the education of artillery officers, is already in the hands of the War Ninister. Judging by the distinguished names of the committee, and the fact that the evidence of no less than 54 artillery officers has been taken, I have no doubt but that their recommeudations will bo duly considered and acted upon. The committeo at all events haro the full confidence and respect of their brother Officers of all ranks.

Iy readers may not have realized the expectations raised by the title of this lecture, which has been turned somewhat from its intended course, for two reasons. It wonld ill become mo to anticipate or guess at the details of the report before alluded to upon the education of Artillery Officers, upon which I was called to give evidence, still less to anticipate that of the Committeo on the Classification of Gunners and Drivers, of which I have Intely had the honom of being appointed Secretiny.

In conclusion, it must be borne in mind that the real brunt of all figliting is borne by the infantry; and it nust not be supposed that I forget this fact, because I am treating only of artillery. No man appreciates snore highly than I do the resolute British infantry "Nulli secuntlus."

There is in our $\Delta$ rmy a class found in no other; Oficers who at their own peril and privato expense hang about contending armies to gain military experience; discouraged by the State, thwarted, and sometimes arrested by both sides. They obtain for us that knowledge which our Govenument frecly offers to all our pessible enemies.

Much valuable information has been giren me by Col. Smythe, R.A., and the artillery brothers, Brackenbury, who have, "cn amateur," encountered the fatigues and daugers of many compaimins. I ani indebted to Lieut. Cunuingliam, of the Artillery, for the highly artistic drawing of a position covering a strategical point, viz., the bridge. Lieut. Gardncr, of the loyal Nary, like a true brother blue jacket, liag assisted me with plans. 